\title{
POTENTIAL APPLICATIONS OF DIETARY Moringa oleifera LEAVES AS GROWTH MODULATOR AND IMMUNOSTIMULANT AGAINST Aeromonas hydrophila FOR FARMED Oreochromis niloticus
}

\author{
Ratchaneegorn Mapanao*), Wirat Jiwyam*), Wilailuk Khrueanet**), and Nudtha Nithikulworawong*\# \\ *) Aquatic Animals Production Technology Program, Faculty of Multidisciplinary Studies, Khon Kaen University, \\ Nong Khai Campus, Nong Khai Province, Thailand, 43000 \\ *) Environmental Science and Natural Resources Program, Faculty of Multidisciplinary Studies, Khon Kaen University, \\ Nong Khai Campus, Nong Khai Province, Thailand, 43000
}

(Received: March 9, 2021; Final revision: September 1, 2021; Accepted: September 2, 2021)

\begin{abstract}
Herbal medicine, including moringa (M oringa oleifera), is widely used as dietary supplementation to enhance growth performance and increase disease resistance in aquaculture. This study aimed to investigate the effects of supplementing moringa leaves on growth performance, hematology and disease resistance of nile tilapia (Oreochromis niloticus) against Aeromonas hydrophila. Fish $(38.05 \pm 0.83 \mathrm{~g}$ ) were fed with a commercial feed supplemented by moringa leaves at $0 \% 15 \% 20 \%$ and $25 \%$ ad libitum, twice a day for eight weeks. Results revealed that $15 \%$ moringa leaves supplemented diet gave the highest weight gain, while the specific growth rate was statistically significantly different $(p<0.05)$ among the treatments. Fish fed with $25 \%$ supplementation had the highest total red blood cell count and total white blood cell count. All experimental groups had higher values of red blood cells and white blood cells than the control group. The challenge test with A. hydrophila showed that the fish fed with the $25 \%$ moringa leaves supplementation diet had the highest relative percentage survival rate. There were no significant differences among the treatment groups. However, the treatment groups had a statistically significant difference with the control group $(p<0.05)$. Results of the present study indicated that supplementation of $15 \%$ moringa leaves in diet gave optimal growth performance, while supplementation of $25 \%$ moringa leaves in the diet showed the best results in terms of the health of nile tilapia. Moringa leaves supplemented in nile tilapia diet enhanced growth performance and increased disease resistance against A. hydrophila.
\end{abstract}

\section{KEYWORDS: moringa leaves; Oreochromis niloticus; Aeromonas hydrophila; hematology}

\section{INTRODUCTION}

Aquaculture is conducted to increase aquatic animal supply as the source of essential protein and micronutrients for human consumption. In 2018, global aquaculture production was 114.5 million tons live weight, with a value of USD 263.6 billion. Total production consisted of 82.1 million tons of aquatic animals, dominated by finfish (54.3 million tons). Between 2001-2018, the global aquaculture production of farmed aquatic animals grew at an average of $5.3 \%$ per annum (FAO, 2020).

Nile tilapia (Oreochromis niloticus) is extensively cultured worldwide, particularly in Asia, Africa, and the

\footnotetext{
\# Correspondence: Aquatic Animals Production Technology Program, Faculty of Multidisciplinary Studies, Khon Kaen University, Nong Khai Campus, Nong Khai Province, Thailand, 43000

E-mail: nudtha@ kku.ac.th
}

United States. Nile tilapia is one of the most important fish in Thai freshwater aquaculture. In 2019, the total freshwater aquaculture production in Thailand was 427,330 tons; worth 25,977.04 million baht. Nile tilapia comprised the highest production volume at 228,982 tons as $53.58 \%$ of the total production, valued at 11,434.46 million baht (Department of Fisheries, 2021). Tilapia fish farming has rapidly expanded throughout the country. Demand for tilapia feed has also continuously increased due to the wide adoption of intensive aquaculture systems, associated with higher stocking density to give higher production per unit area. Over the past three decades, fishmeal prices have also steadily increased with demand, negatively affecting commercial aquaculture profitability. In response to the limited production of fishmeal and the rising price trend, many studies have been conducted to find alternative sources of animal and plant protein for aquaculture. The poten- 
tial of plant-based protein replacement is high and will probably become the primary substitute of fishmeal in aquaculture feed (Olsen \& Hasan, 2012). The rapid intensified expansion of aquaculture has also induced negative consequences, including poor growth, poor health, and increased susceptibility to disease, leading to death in extreme cases. Fish farmers are facing difficulties in converting biological gain into economic benefits. Chemotherapeutic agents and antibiotics have been used to maintain the health of farmed fish. However, this approach is profit-driven and unsustainable, causing many other knock-on effects such as fish pathogen drug resistance, immunosuppression, and accumulation of chemical residues that impact environmental pollution and public health (Bulfon et al., 2013). Therefore, economical, environmentally friendly and sustainable methods are urgently required to improve aquaculture production. Recently, the immune-stimulating function of medicinal herbs has attracted interest in aquaculture, with herbal additives used as growth promoters, stress resistance boosters and preventatives of infections in fish. Moreover, herbal treatment is cost-effective and eco-friendly, with minimal side effects. Medicinal herbal extracts to improve aquaculture production show high potential as an alternative to chemical agents.

Moringa (M oringa oleifera) is native to Northeastern India and grows in tropical and subtropical regions. Moringa has long been used in traditional medicine. The plant has high nutritional value, and every part can be used for either nutritional or commercial purposes. Moringa leaves are rich in crude protein, with content varying from $25 \%$ to $32 \%$ Minerals, vitamins, fiber, fat, proteins, and other essential phytochemicals were found at high levels in the leaves (Jung, 2014). Moringa leaves supplemented in fish diets improved growth promoters and immunostimulants and reduced disease in nile tilapia (0. niloticus) (Sherif et al., 2014; El-Gawad et al., 2020), Mozambique tilapia (0. mossambicus) (Mbokane \& Moyo, 2018), African catfish (Clarias gariepinus) (Ozovehe, 2013), common carp (Cyprinus carpio) (Khalil $\&$ Korni, 2017), Bocourti's catfish (Pangasius bocourti) (Puycha et al., 2017), and Indian major carp (Labeo rohita) (Hussain et al., 2018). Here, the study aimed to determine the effects of moringa leaves on growth performance, hematology and disease resistance against $A$. hydrophila in nile tilapia.

\section{MATERIALS AND METHODS}

\section{Experimental Diet Preparation}

Fresh moringa leaves were collected from Nong Khai Province, Thailand. The leaves were washed with distilled water and oven-dried at $60^{\circ} \mathrm{C}$ for three days.
The dried leaves were then ground into a fine powder and mixed with a commercial diet for nile tilapia containing $35 \%$ crude protein at different levels of moringa as follows: $0 \%$ (control), $15 \% 20 \%$ and $25 \%$ using Alpha Star as a food binder. The experimental diets were stored at $4^{\circ} \mathrm{C}$ and freshly prepared every week. Proximate and chemical compositions of moringa leaves are shown in Table 1 (Chatepa \& Mbewe, 2018).

Table 1. Proximate and chemical composition of moringa leaves

\begin{tabular}{lc}
\hline \multicolumn{1}{c}{ Parameter } & Value \\
\hline Proximate composition (\%) & \\
Dry matter & $93.78 \pm 0.07$ \\
crude protein & $22.60 \pm 0.17$ \\
crude fibre & $8.07 \pm 0.17$ \\
Crude fat & $13.40 \pm 025$ \\
Ash & $11.24 \pm 0.15$ \\
Carbohydrate & $44.69 \pm 0.41$ \\
\hline Chemical composition (\%) & \\
Gross energy (Mcal/kg DM) & $3.8 \pm 0.0$ \\
Metabolisable energy (Mcal/kg DM) & $3.3 \pm 0.0$ \\
Fatty acids (g/kg DM) & $107.2 \pm 2.0$ \\
pH & $6.35 \pm 0.0$ \\
Titratable acidity (g/100 g oleic acid) & $3.8 \pm 0.0$ \\
Phosphorus (mg/100 g DM) & $427.6 \pm 33.9$ \\
\hline
\end{tabular}

Source: Chatepa \& Mbewe (2018)

\section{Experimental Fish}

Nile tilapia with an initial weight of $38.05 \pm 0.83$ $g$ were obtained from the hatchery of aquatic animals production technology program, Khon Kaen University, Nong Khai Campus, Nong Khai Province. The fish were acclimatized in laboratory conditions for one week before starting the feeding trials. At the beginning of the experiment, 12 aquaria containers $(0.45 \mathrm{~m} \times 0.90 \mathrm{~m} \times 0.45 \mathrm{~m}$, water volume 150 liters) were each stocked with 17 fish. Each experimental diet was fed to fish in three aquaria. Half of the water volume in all of the experimental aquaria was changed daily. The fish were fed with the diet of moringa leaves twice daily at 09:00 and 15:00 for eight weeks ad libitum.

\section{Growth Performance}

At the end of the feeding trials, all fish were individually weighed. The growth parameters were calculated:

$$
W G=(W f-W i)
$$

$$
\text { where: } \begin{aligned}
W G & =\text { weight gain } \\
W i & =\text { initial mean weight }(\mathrm{g}) \\
W f & =\text { final mean weight }(\mathrm{g})
\end{aligned}
$$




$$
A D G=\frac{(W f-W i)}{\text { Culture period (days) }}
$$

$$
\text { where: } \begin{aligned}
\text { ADG } & =\text { average daily weight gain } \\
W i & =\text { initial mean weight }(\mathrm{g}) \\
W f & =\text { final mean weight }(\mathrm{g}) \\
\mathrm{SGR} & =100 \frac{[(\operatorname{InWf}-\operatorname{InWi})]}{\text { cultue period (days) }}
\end{aligned}
$$

where: $S G R=$ specific growth rate

$$
W i=\text { initial mean weight }(\mathrm{g})
$$

$W f \quad=$ final mean weight $(\mathrm{g})$

$$
\mathrm{SR}=100 \frac{\mathrm{Nf}}{\mathrm{Ni}}
$$

where: $S G R=$ specific growth rate

$\mathrm{Nf}=$ final number of fish

$\mathrm{Ni}=$ initial number of fish

\section{Hematological Analysis}

After final weighing, three fish from each group were randomly anesthetized at the end of the growth trial. Blood was collected from the caudal vein using a $1 \mathrm{~mL}$ sterile syringe coated with an anticoagulant. Hematological variables measured were red blood cell count and white blood cell count using a hemocytometer according to (Blaxhall \& Daisley, 1973).

\section{Challenge Experiments}

After eight weeks, 10 fish from each group were randomly collected and challenged by an intraperitoneal injection of $0.2 \mathrm{~mL}$ of Aeromonas hydrophila culture containing $0.3 \mathrm{CFU} \cdot \mathrm{mL}^{-1}$ according to Schaperclaus et al. (1992) as the lethal dose for tilapia. The injected fish were kept under observation for 10 days to record the mortality rate (MR) percentage calculated as:

$$
M R=\frac{\text { Number of death } \text { in specific period }}{\text { Total population during that period }} \times 100
$$

The relative percent survival (RPS) was calculated in terms of vaccine efficacy according to Ellis (1988).

$$
\text { RPS }=1-\frac{\text { (Percent mortalityin treated group) }}{\text { (Percent mortality in control group })} \times 100
$$

\section{Statistical Analysis}

Data from each treatment were subjected to oneway analyses of variance (ANOVA) using SPSS for W indows version 17.0 (SPSS Inc., Chicago, U.S.A.). Means were compared after analysis of variance by Duncan's New Multiple Range Test $(p=0.05)$. The significance level was chosen at $p \leq 0.05$, with results presented as mean \pm standard deviation.

\section{Ethics Statement}

All study methods and experimental procedures were conducted following the guidelines and regulations reviewed and approved by the Institutional Animal Care and Use Committee of Khon Kaen University, based on the Ethics of Animal Experimentation of the National Research Council of Thailand (Reference No. 0201.2.11/13).

\section{RESULTS AND DISCUSSION}

The effects of moringa leaves as a dietary supplement on growth performance, hematology, and disease resistance against $A$. hydrophila in nile tilapia were investigated. Many herbs have been used as dietary supplements to investigate antimicrobial activity against fish pathogenic bacteria, including mulberry (M orus alba Linn.) (Bag et al., 2012; Mapanao et al., 2019), Sirindhorn-vallee (Bauhinia sirindhorniae) (Nithikulworawong, 2012), and ginger (Zingiber officinale) (Negm et al., 2016). Moringa leaves are wellknown for their bactericidal potential (Ijarotimi et al., 2013); however, scant information is available on the antimicrobial activity of moringa against fish pathogens.

\section{Effect of Supplementing Diet with Moringa Leaves on Growth Performance}

The growth performances of nile tilapia fed with the artificial feed containing moringa leaves at $0 \%$ (control), $15 \% 20 \%$ and $25 \%$ for eight weeks are shown in Table 2. The highest weight gain (WG), average daily weight gain (ADG), and specific growth rate (SGR) were found in fish groups fed with the diets containing $15 \%$ mo ringa leaves at $64.51 \mathrm{~g}^{1.08 \mathrm{gd}^{-1} \text {, and } 1.66 \%}$ $d^{-1}$, respectively with statistically significant differences between the treatments $(p<0.05)$. The fish groups fed with the feed containing moringa leaves at 15\%had the highest survival rate of $98.04 \pm 3.40 \%$ with no statistical differences among the treatments $(p>0.05)$.

The results indicated an optimal growth performance of nile tilapia in fish groups fed with the artificial feeds containing moringa leaves at $15 \%$ with no significant statistical difference from the control group. This result indicated that moringa leaves at $15 \%$ in the artificial feeds did not affect the growth performance of nile tilapia, while this dosage was within acceptable limits. These findings concurred with Hussain et al. (2018) found no effect of $30 \%$ and $40 \%$ levels of moringa leaves as fishmeal replacement on the growth performance of Indian major carp (Labeo 
Potential applications of dietary Moringa oleifera a leaves ..... (Ratchaneegorn Mapanao)

Table 2. Growth performance of nile tilapia fed with the experimental feed for 8 weeks (Mean \pm SD)

\begin{tabular}{lccccc}
\hline \multirow{2}{*}{$\begin{array}{c}\text { Growth } \\
\text { performance }\end{array}$} & \multicolumn{4}{c}{ Moringa leaves of different levels in artificial feeds $(\%)$} & P-value \\
\cline { 2 - 6 } & $\mathbf{0}$ & $\mathbf{1 5}$ & $\mathbf{2 0}$ & $\mathbf{2 5}$ & \\
\hline Weight gain $(\mathrm{g})$ & $59.80 \pm 1.13^{\mathrm{a}}$ & $64.51 \pm 7.11^{\mathrm{a}}$ & $48.56 \pm 4.10^{\mathrm{b}}$ & $41.05 \pm 5.95^{\mathrm{b}}$ & 0.002 \\
Average daily weight gain $\left(\mathrm{g} \cdot \mathrm{fish}^{-1} \cdot \mathrm{d}^{-1}\right)$ & $1.00 \pm 0.02^{\mathrm{a}}$ & $1.08 \pm 0.12^{\mathrm{a}}$ & $0.81 \pm 0.07^{\mathrm{b}}$ & $0.68 \pm 0.10^{\mathrm{b}}$ & 0.002 \\
Specific growth rate $\left(\% \mathrm{~d}^{-1}\right)$ & $1.57 \pm 0.03^{\mathrm{ab}}$ & $1.66 \pm 0.13^{\mathrm{a}}$ & $1.37 \pm 0.09^{\mathrm{bc}}$ & $1.21 \pm 0.15^{\mathrm{c}}$ & 0.004 \\
Survival rate $(\%)$ & $96.08 \pm 3.40$ & $98.04 \pm 3.40$ & $94.12 \pm 0.00$ & $92.16 \pm 3.40$ & 0.163 \\
\hline
\end{tabular}

Note: Means within the same row with different, lowercase, superscript letters are signiûcantly different $(p<0.05)$

rohita) fingerlings. Moringa leaves substituted fishmeal at up to $15 \%$ without any adverse effects on growth and feed efficiency in African catfish (Clarias gariepinus) fingerling diets by Idowua et al. (2017). Other studies also showed no significant effect of moringa leaves incorporated in the diets of nile tilapia at 1.5\%and 5\%(El-Gawad et al., 2020) and 5\% 10\% and $15 \%$ (Yuangsoi \& Charoenwattanasak, 2011). Additionally, dietary supplements of moringa leaves at $3 \%$ 6\% 9\% and 12\%in M ozambique tilapia (Oreochromis mossambicus) (Mbokane \& Moyo, 2018) and 15\% in redtail mystus (Hemibagrus wyckioides) recorded no significant differences in growth efficiency (Phommanivong \& Doolchidachabaporn, 2013). However, dietary incorporation of $10 \mathrm{~g}$ of moringa leaves/ $\mathrm{kg}$ feed and $20 \mathrm{~mL}$ of moringa leaves aqueous extract $/ \mathrm{kg}$ feed increased the final weight and specific growth rate of common carp (Cyprinus carpio) fingerlings (Khalil \& Korni, 2017).

On the other hand, fish fed moringa leaves added to the artificial diet at more than $15 \%(20 \%$ and $25 \%$ showed decreased WG, ADG, and SGR. This finding concurred with other studies conducted on nile tilapia fed with dietary moringa leaves at $20 \%$ and $25 \%$ (Sherif et al., 2014). Fancy carp (C. carpio) fed with protein-replacing moringa leaves at $500 \mathrm{~g} \mathrm{~kg}^{-1}$ (Yuangsoi \& Masumoto, 2012) also exhibited a decrease in growth efficiency. In another study, the growth performance of Bocourti's catfish (Pangasius bocourti) decreased significantly $(p<0.05)$ when moringa leaves content was increased in their diet (Puycha et al., 2017). The reduced growth was caused by saponins and other antinutritional in moringa, affecting feed palatability (Madalla et al., 2013). The antinutritional factors are detrimental to fish health at high dosages, which interfere with digestive enzymes and reduce the availability of nutrients (Makkar et al., 2007). Amounts of condensed tannin in the diet at more than $2 \%$ also caused less feed acceptance by the animals and reduced growth. At the same time, low digestible plant material inhibited the use of other nutrients in fish diets (Dongmeza et al.,
2010). The saponin has a negative effect on the biological membranes that act as a surface-active component, leading to the intestinal mucosal cells permeability increasing and affecting active nutrients transportation. Moreover, phytate reduces the minerals bioavailability and the protein digestibility through phytic acid-protein complexes, which restrain the nutrient absorption (Hlophe \& Moyo, 2014).

\section{Effect of Supplementing Diets with Moringa Leaves on Hematological Parameters}

Hematological parameters of moringa leaves contained in artificial feeds at $0 \% 15 \% 20 \%$ and $25 \%$ for nile tilapia for eight weeks are shown in Table 3. Results showed that the number of red and white blood cells in the experimental groups increased. The fish group fed with $25 \%$ moringa leaves artificial feed had the highest red blood cell count of $5.09 \times 0^{6} \pm 0.55 \times$ $10^{6}$ cell. $\mu \mathrm{L}^{-1}$, with no statistically significant differences between the different groups. White blood cell counts were not significantly different among fish fed with artificial feeds ranging from $6.09 \pm 2.96$ to $7.83 \pm$ $2.76 \times 10^{3}$ cell. $\mu \mathrm{L}^{-1}$. The fish group fed moringa leaves artificial feed at $25 \%$ had the highest white blood cell count. Fish in all experimental groups had higher white blood cell counts than fish in the control group.

Table 3. Hematological parameters of nile tilapia fed with experimental feeds (M ean \pm SD)

\begin{tabular}{ccc}
\hline $\begin{array}{c}\text { Level of Moringa } \\
\text { leaves }(\boldsymbol{\%})\end{array}$ & $\begin{array}{c}\text { Red blood cell } \\
\left(\mathbf{\times 1 0 ^ { 6 }} . \boldsymbol{\mu L}^{-1}\right)\end{array}$ & $\begin{array}{c}\text { White blood cell } \\
\left(\times 10^{3} \cdot \boldsymbol{\mu L}^{-1}\right)\end{array}$ \\
\hline 0 & $3.82 \pm 1.98$ & $6.09 \pm 2.96$ \\
15 & $4.36 \pm 1.03$ & $6.17 \pm 7.63$ \\
20 & $4.78 \pm 0.19$ & $7.08 \pm 1.76$ \\
25 & $5.09 \pm 0.55$ & $7.83 \pm 2.76$ \\
\hline P-value & 0.588 & 0.750 \\
\hline
\end{tabular}

Many factors including species, size, age, physiological status, environmental conditions, dietary regime, quality, and quantity of diet were reported 
to affect fish hematological parameters. Normal values of these parameters relate to dietary ingredients, protein sources, vitamins, and probiotics. The study of hematological values is also useful for physiological examination of changes in fish health or determining the state of health. Complete blood cell count (CBC) is an important and effective diagnostic tool that can be used to monitor fish health status in response to changes in nutrition, water quality, and disease therapy (Fazio, 2019). Hematological test results included red blood cell (RBC) and white blood cell (WBC) counts. Values of RBC and WBC were higher than those found in tilapia by Martins et al. (2008) and Sayed \& Moneeb (2015) in normal conditions. In this study, RBC and WBC counts in fish fed with moringa leaves-supplemented diets increased as the amount of moringa leaves in the diet increased. The increase of RBC and WBC indicated that the health of nile tilapia improved with the dietary addition of moringa leaves. These results were identical to research conducted on Mozambique tilapia by Mbokane $\&$ Moya (2018) that showed an increase in WBC and RBC of fish fed with the highest dosages of moringa leaves. Likewise, African catfish fed with 10\% to 50\% moringa leaves as fish meal substitution in diets showed an increase in WBC count (Ozovehe, 2013). An increase in WBC count is often associated with microbial infection or the presence of foreign bodies or antigens in the circulatory system (Oyawoye $\&$ Ogunkunle, 1998). These results contrasted with Ozovehe (2013), who recorded a decrease in RBC count of African catfish fed on moringa leaves as fish meal substitution in diets and considered this decrease to be associated with higher antimetabolite concentrations, especially tannin in moringa leaves. Sherif et al. (2014) found that nile tilapia fed $10 \%$ to $15 \%$ and $25 \%$ to $30 \%$ moringa leaves in diets showed a significant increase and decrease in WBC counts, respectively. This difference suggested that the results depended on many factors, including fish species, fish size, fish physiological status, dose, and duration of supplementation. Although both RBC and WBC values of all treatments were not statistically different, they were higher than the control group. This suggested that moringa leaves had rich nutritional properties, especially polysaccharides, essential vitamins and nonessential amino acids, which are required to synthesize hemoglobin (Latona et al., 2012). Hematopoietic index improvement might be caused by the ability of moringa leaves to stimulate erythropoiesis. It increases oxygen transport capability and strengthens the fish's defense mechanisms against physiological stress (Gabriel, 2019). Therefore, supplementing artificial feeds with moringa leaves promoted the health of nile tilapia.
Table 4. Mortality rate of nile tilapia after A. hydrophila injection for 10 days (mean $\pm \mathrm{SD}$ )

\begin{tabular}{cc}
\hline $\begin{array}{c}\text { Level of moringa } \\
\text { leaves in diet }(\%)\end{array}$ & $\begin{array}{c}\text { Mortality rate } \\
\text { (\%) }\end{array}$ \\
\hline 0 & $86.67 \pm 15.28^{\mathrm{a}}$ \\
15 & $63.33 \pm 15.28^{\mathrm{ab}}$ \\
20 & $56.67 \pm 11.55^{\mathrm{b}}$ \\
25 & $43.33 \pm 5.77^{\mathrm{b}}$ \\
\hline P-value & 0.017 \\
\hline
\end{tabular}

Note: Within the same column with different, lowercase, superscript letters are signiûcantly different $(p<0.05)$

\section{Effect of Supplementing Artificial Feed with Moringa Leaves on Disease Resistance Against Aeromonas hydrophila}

After the challenge test, the lowest mortality rate was found in fish fed with moringa leaves in artificial feed at $25 \%$ with an average of $43.33 \pm 5.77 \%$ (Table 4). There were no statistically significant differences between the treatments, but all showed statistically significant differences with the control $(p<0.05)$. Fish fed with artificial feed containing moringa leaves at $25 \%$ also showed the highest relative percent survival (RPS) at 51\% There were no statistically significant differences between the treatments, but all showed statistically significant differences with the control $(p<0.05)$. The control group progressed to clinical disease and died 24 hours after the challenge, while fish fed on moringa leaves artificial feed at $15 \% 20 \%$ and $25 \%$ began to die after 48,72 , and 96 hours, respectively (Figure 1).

Results of the challenge test with A. hydrophila showed that the mortality rate was lowest $(43.33 \%$ in the fish group fed with feed containing $25 \%$ moringa leaves, followed by those fed with $20 \%$ (56.67\%mortality) and $15 \%(63.33 \%$ mortality) moringa leaves-supplemented diets compared with the control. The mortality rate parameter in moringa leaves treatments showed lower values than the control group. Fish groups fed with artificial feed containing $25 \%$ of moringa leaves showed the highest survivability, followed by fish groups fed with artificial feed containing $15 \%$ and $10 \%$ of moringa leaves. Moreover, the relative percent of survival (RPS), as one of the most visually observed parameters of immune evaluation in the challenge test, was higher in all fish groups fed with artificial feed containing moringa leaves than in the control group. The observed increase in RPS against A. hydrophila indicated that incorporating moringa leaves in the diet helped nile 


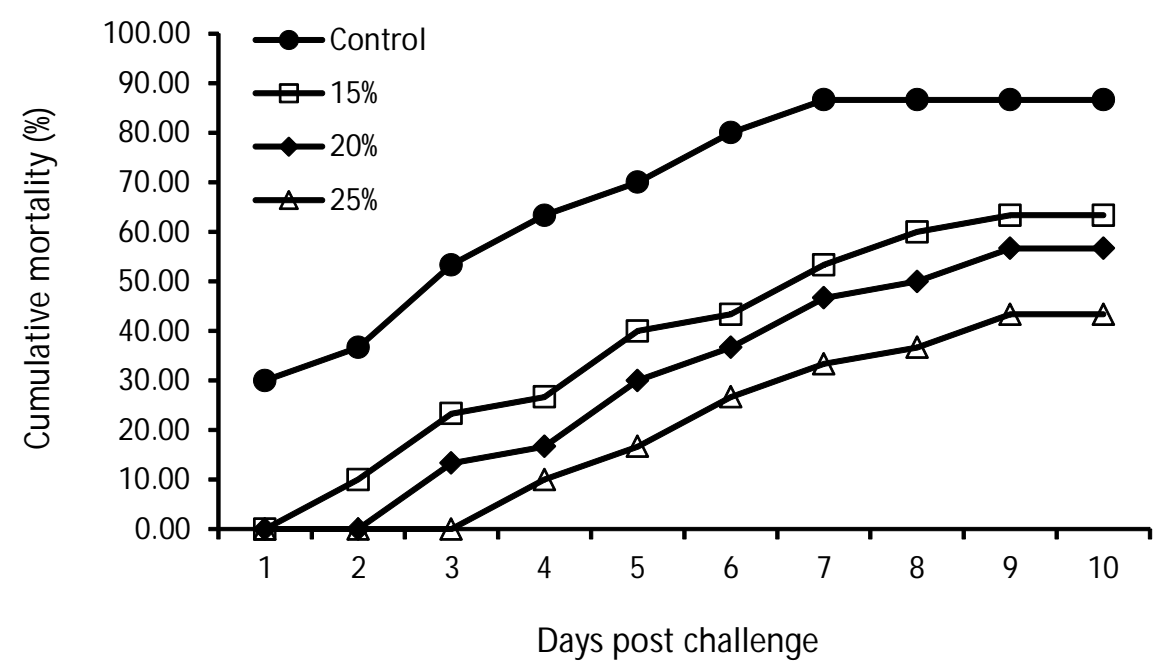

Figure 1. Mortality rate of nile tilapia fed artificial feeds incorporated with moringa leaves and challenge with Aeromonas hydrophila.

tilapia resist bacterial invasion through immunomodulatory activity and improved resistance against pathogens compared to the control group. The increase in WBC indicates an increase in the immune status and the suppression of infection in these groups. Ayoola (2011) noted that lymphocytes are the most numerous cells comprising the leucocytes, which function in the antibodies production, and chemical substances act as a defense against infection. This finding suggests that moringa leaves may boost many humoral factors such as serum bactericidal activity lysozyme, total protein, and C3 to provide protection during pathogen invasion (Wang et al., 2016). Gopalakrishnan et al. (2016) stated that moringa leaves extracts are used as potential antioxidant, anticancer, anti-inflammatory, antidiabetic, and antimicrobial agents. These antibacterial activities include 4(4'-0-acetyl- $\alpha$-L-rhamnopyranosyloxy) benzyl isothiocyanate, 4-( $\alpha$-L-rhamnopyranosyloxy) benzyl isothiocyanate, niazimicin, pterygospermin, benzyl isothiocyanate, and 4-( $\alpha$-L-rhamnopyranosyloxy benzyl glucosinolate (Fahey, 2005). Additionally, moringa has been widely reported to contain constituents such as nitrile, glycosides, and quercetin (Kaleeswaran et al., 2011), which are responsible for immunity-enhancing against microbial diseases. Hammed et al. (2015) also reported that potent antioxidants in moringa leaves can be associated with increased production of antibodies that aid in the survival and regeneration of fish during times of stress. Following the same trend, survival rates and RPS values of Mozambique tilapia (M bokane \& Moyo, 2018) and nile tilapia (El-Gawad et al., 2020) after challenge with $A$. hydrophila increased with increasing moringa leaves dosage. Mortality reduction of fish fed with moringa leaves after injection of A hydrophila was consistent with previous studies of other herbs; for example, nile tilapia fed with a diet containing Morus alba Linn. (Mapanao et al., 2019), Labeo rohita fed with a diet containing Achyranthes aspera (Chakrabarti et al., 2012; Kumar et al., 2019), and Ocimum sanctum Linn. (Das et al., 2015). Our results indicated that moringa leaves could be used as an essential ingredient in feed for fish species to enhance immunity against common fish pathogens.

These research findings reiterate that moringa leaves are highly nutritious and contain antioxidants and antimicrobial agents. An optimum supplementation of moringa leaves in fish feed can promote growth, encourage the immune response and support better fish health. Moringa could be used as an alternative fish feed ingredient. However, the in vivo efficiency of this herb to enhance fish immunity and reduce the effects of its contained toxins require further investigation. Appropriate field trials are necessary before a government authorizes moringa leaves as an immunomodulator for aquaculture fish species.

\section{CONCLUSION}

This study successfuly investigated the effect of moringa leaves on growth performance, hematology and disease resistance of nile tilapia against Aeromonas hydrophila. Moringa leaves could be used as a dietary supplement at not more than 15\%to support growth performance and at up to $25 \%$ to control infection caused by A. hydrophila in nile tilapia. Supplementation of moringa leaves can be used as an herbal growth-promoting and heath improving agent in fish feed based on the performance of nile tilapia. Field studies on the efffectiveness of moringa leaves in enhancing fish immunity and reducing the effects of existing toxins still require further research. 


\section{ACKNOWLEDGEMENT}

We gratefully acknowledge the support received from the Research and Technology Transfer Affairs of Khon Kaen University.

\section{REFERENCE}

Ayoola, S.O. (2011). Haematological characteristics of Clarias gariepinus (Buchell, 1822) juveniles fed with poultry hatchery waste. Iranica Journal of Energy \& Environment, 2(1), 18-23.

Bag, M.P., Ghorai, M., Mahapatra, S.C., Rao, P.S., \& Pal, H. (2012). Evaluation of mulberry (M orus alba, Linn.) leaf meal as a complete diet of sting fish (Heteropneustes fossilis, Bloch). International Journal of Pharmacy \& Life Science, 3(9), 1965-1969.

Blaxhall, P.C. \& Daisley, K.W. (1973). Routine haematological methods for use with fish blood. Fish Biology, 5, 771-781. doi: 10.1111/j.10958649.1973.tb04510.x.

Bulfon, C., Volpatti, D., \& Galeotti, M. (2013). Current research on the use of plant-derived product in farmed fish. Aquaculture Research, 46, 513-551.

Chakrabarti, R., Srivastava, P.K., Kundu, K., Khare, R.S., $\&$ Banerjee, S. (2012). Effect of dietary supplementation with Achyranthes aspera seed on larval rohu Labeo rohita challenged with Aeromonas hydrophila. Journal of Aquatic Animal Health, 24(4), 213-218.

Chatepa, L.E.C. \& M bewe, E.C. (2018). Proximate, physical and chemical composition of leaves and seeds of moringa (Moringa oleifera) from Central Malawi: A potential for increasing animal food supply in the $21^{\text {st }}$ century. African Journal of Agricultural Research, 13(51), 2872-2880. DOI: 10.5897/ AJAR2018.13535.

Das, R., Raman, R.P., Saha, H., \& Singh, R. (2015). Effect of Ocimum sanctum Linn. (Tulsi) extract on the immunity and survival of Labeo rohita (Hamilton) infected with Aeromonas hydrophila. Aquaculture Research, 46, 1111-1121.

Department of Fisheries. (2021). Statistics of freshwater aquaculture production 2019. Ministry of Agriculture and Cooperatives, Thailand, No.1/ 2021.

Dongmeza, E.B., Francis, G., Steinbronn, S., Focken, U., \& Becker, K. (2010) Investigations on the digestibility and metabolizability of the major nutrients and energy of maize leaves and barnyard grass in grass carp (Ctenopharyngo donidella). Aquaculture Nutrition, 16, 313-326.
El-Gawad, E.A.A., El Asely, A.M., Soror, E.I., Abbass, A.A., \& Austin, B. (2020). Effect of dietary M oringa oleifera leaf on the immune response and control of Aeromonas hydrophila infection in nile tilapia (Oreochromis niloticus) fry. Aquaculture International, 28, 389-402. https://doi.org/10.1007/s10499-01900469-0.

Ellis, A.E. (1988). General principles of fish vaccination. In Ellis, A.E. (Ed.). London: Academic Press, Fish Vaccination, p. 1-19.

Fahey, J.W. (2005). Moringa oleifera: A review of the medical evidence for its nutritional, therapeutic, and prophylactic properties. Part 1. Trees for Life Journal, 1, 5. https://doi.org/10.1201/ 9781420039078.ch12.

Fazio, F. (2019). Fish hematology analysis as an important tool of aquaculture: A review. Aquaculture, $500,237-242$.

Food and Agriculture Organization of the United Nations, Fisheries and Aquaculture Department [FAO]. (2020). The state of world fisheries and aquaculture 2020. Sustainability in action. Rome. https://doi.org/10.4060/ca9229en.

Gabriel, N.N. (2019). Review on the progress in the role of herbal extracts in tilapia culture. Cogent Food \& Agriculture, 5, 1619651.

Gopalakrishnan, L., Doriya, K., \& Kumar, D.S. (2016). Moringa oleifera: A review on nutritive importance and its medicinal application. Food Science and Human Wellness, 5, 49-56.

Hammed, A.M., Amosu, A.O., Awe, A.F., \& Gbadamosi, F.F. (2015). Effects of M oringa oleifera leaf extracts on bacteria (Aeromonas hydrophila) infected adults African mud cat fish. International Journal of Current Research, 7(10), 22117-22122.

Hlophe, S.N. \& Moyo, N.A.G. (2014). Replacing fishmeal with kikuyu grass and moringa leaves: effects on growth, protein digestibility, histological and haematological parameters in Clarias gariepinus. Turkish Journal of Fisheries and Aquatic Sciences, 14, 795-806. DOI: 10.4194/1303-2712v14_3_22.

Hussain, S.M., Arsalan, M.Z.H., Javid, A., Hussain, A.I., Aslam, N., Ali, Q., Hussain, M., Rehan, M.M.H., Shahzad, M.M., Khalid, A., \& Riaz, D. (2018). Replacement of fish meal with Moringa oleifera leaf meal (M.O.L.M.) and its effect on growth performance and nutrient digestibility in Labeo rohita fingerlings. Pakistan Journal of Zoology, 50(5), 18151823. 
Idowua, E., Adewumib, A., Osoc, J., Edwardd, J., \& Obaronbie, G. (2017). Effects of varying levels of Moringa oleifera on growth performance and nutrient utilization of Clarias gariepinus post-fingerlings. American Scientific Research Journal for Engineering, Technology, and Sciences (A.S.R.J.E.T.S.), 32(1), 79-95.

Ijarotimi, 0.S., Adeoti, 0., \& Ariyo, 0. (2013). Comparative study on nutrient composition, phytochemical, and functional characteristics of raw, germinated, and fermented Moringa oleifera seed flour. Food Science and Nutrition, 1, 452-463.

Jung, I.L. (2014). Soluble extract from M oringa oleifera leaves with a new anticancer activity. PLOS ONE, 9, 1-10.

Kaleeswaran, B., Ilavenilb, S., \& Ravikumara, V. (2011). Dietary supplementation with Cynodon dactylon (L.) enhances innate immunity and disease resistance of Indian major carp, Catla catla (Ham.). Fish and Shellfish Immunology, 31, 953-962.

Khalil, F. \& Korni, F.M.M. (2017). Evaluation of M oringa oleifera leaves and their aqueous extract in improving growth, immunity and mitigating effect of stress on common carp (Cyprinus carpio) fingerlings. Turkish Journal of Aquatic Sciences, 32, 170177.

Kumar, N., Sharma, J, Singh, S.P., Singh, A., Krishna, V.H., \& Chakrabart, R. (2019). Validation of growth enhancing, immunostimulatory and disease resistance properties of Achyranthes aspera in Labeo rohita fry in pond conditions. Heliyon, 5(2), e01246. j.heliyon.2019.e01246.

Latona, D.F., Oyeleke, G., \& Olayiwola, O. (2012). Chemical analysis of ginger root. Journal of Applied Chemistry, 1(1), 47-49.

Madalla, N., Agbo, N.W., \& Jauncey, K. (2013). Evaluation of aqueous extracted Moringa leaf meal as a protein source for nile tilapia juveniles. Tajas, 12(1), 53-64.

Makkar, H.P.S., Francis, G., \& Becker, K. (2007). Bioactivity of phytochemicals in some lesser-known plants and their effects and potential applications in livestock and aquaculture production systems. Animal, 1, 1371-1391.

Mapanao, R., Churnate, W., \& Nithikulworawong, N. (2019). Antibacterial property and potential use mulberry leaves (Morus alba Linn.) as dietary supplement on growth performance and disease resistance against Aeromonas hydrophila in nile tilapia (Oreochromis niloticus). Journal of Science and Technology Ubon Ratchathani University, 21(2), 1-9.
Martins, M.L., Mouriño, J.L.P., Amaral, G.V., Vieira, F.N., Dotta, G., Jatobá, A.M.B., Pedrotti, F.S., ....., \& Pereira-Jr, G.A. (2008). Haematological changes in nile tilapia experimentally infected with Enterococcus sp. Brazilian Journal of Biology, 68(3), 657661.

Mbokane, E.M. \& Moyo, N.A.G. (2018). Alterations of haemato-biochemical parameters pre and postchallenge with Aeromonas hydrophila and survival of Oreochromis mossambicus fed Moringa oleiferabased diets. Fish and Shellfish Immunology, 83, 213222.

Negm, I.M., El Asely, A.M., \& Abbass, A.A. (2016). Influence of dietary ginger (Zingiber officinale) on haemato-biochemical parameters, spleen histopathological changes and resistance of Oreochromis niloticus fingerlings. Egyptian Journal for Aquaculture, 6, 25-45.

Nithikulworawong, N. (2012). Efficacy of Bauhinia sirindhorniae on resistance to against Streptococcus agalactiae in nile tilapia (Oreochromis niloticus). KKU Research Journal, 17(5), 715-724.

Olsen, R.L. \& Hasan, M.R. (2012). A limited supply of fishmeal: Impact on future increases in global aquaculture production. Trends in Food Science \& Techology, 27, 120-128. https://doi.org/10.1016/ j.tifs.2012.01.008.

Oyawoye, E.O. \& Ogunkunle, M. (1998). Physiological and biochemical effects of raw jack beans on broilers. In Annual Conference of Nigerian Society of Animal Production, p. 141-142.

Ozovehe, B.N. (2013). Growth performance, hematological indices and some biochemical enzymes of juveniles Clarias gariepinus (Burchell 1822) fed varying levels of Moringa oleifera leaf meal diet. Journal of Aquaculture Research \& Development, 4, 166-172.

Phommanivong, S. \& Doolchidachabaporn, S. (2013). Effects of moringa's leave supplementary diet on growth performances and survival rate of redtail mystus (Hemibagrus wyckioides). Journal of Fisheries Technology Research, 7(1), 9-19.

Puycha, K., Yuangsou, B., Charoenwattanasak, S., Wongmaneeprateep, S., Niamphithak, P., \& W iriyapattanasub, P. (2017). Effect of moringa (M oringa oleifera) leaf supplementation on growth performance and feed utilization of Bocourti's Catfish (Pangasius bocourti). Agricultural and Natural Resources, 51, 286-291.

Sayed, A.E.D.H. \& Moneeb, R.H. (2015). Hematological and biochemical characters of monosex tilapia 
(Oreochromis niloticus, Linnaeus, 1758) cultivated using methyltestosterone. The Journal of Basic \& Applied Zoology, 72, 36-42.

Schaperclaus, W., Kulow, H. \& Schrecken-bach, K. (1992). Fish diseases. In Balkema, A.A. (Ed.). Fish diseases. $5^{\text {th }}$ Ed. Rotterdam, The Netherlands.

Sherif, A.H., El-Gamal, A.M., \& Tolan, A.E. (2014). Incorporation of Moringa oleifera leaf in nile tilapia Oreochromis niloticus diet and its effect on growth performance and immune status. Journal of Veterinary Science, 1(1), 806-814.

Wang, E. Chen, X., Wang, K., Wang, J., Chen, D., Geng, Y., Lai, W., \& Wei, X. (2016). Plant polysaccharides used as immunostimulants enhance innate im- mune response and disease resistance Aeromonas hydrophila infection in fish. Fish \& Shellfish Immunology, 59, 196-202.

Yuangsoi, B. \& Charoenwattanasak, S. (2011). Utilization of (M oringa oleifera Lam.) leaf on $\mathrm{g} \mathrm{row} t \mathrm{~h}$ performance and protein digestibility in Tilapia (Oreochromis niloticus L.). In $49^{\text {th }}$ Kasetsart University Annual Conference: Fisheries, p. 317-326. Kasetsart University, Thailand.

Yuangsoi, B. \& Masumoto, T. (2012). Replacing moringa leaf (M oringa oleifera) partialling by protein replacement in soybean meal of fancy carp (Cyprinus carpio). Songklanakarin Journal of Science and Technology, 34(5), 479-485. 